Recepción: 22 / 01 / 2018

Aceptación: 17 / 02 / 2018

Publicación: 21 / 03 / 2018

Ciencias de la Educación Artículo de Revisión

\title{
La educación a distancia y el desempeño académico de los estudiantes
}

\author{
Distance education and academic performance of students
}

La educación um distancia y el desempeño académico de los estudiantes

\author{
Elsa Ortiz-Gaona ${ }^{\mathrm{I}}$ \\ elsita3111@hotmail.com \\ Luisa G. González-González II \\ luisag37@hotmail.com \\ Silvana A. Rodríguez-Granda III \\ silvana_rodriguez@hotmail.com \\ Magaly E. Cedeño-Azanki IV \\ mecedeno@utm.edu.ec
}

Correspondencia: elsita3111@ hotmail.com

\footnotetext{
${ }^{\text {I }}$ Docente de la Universidad Nacional de Loja, Loja Ecuador

${ }^{\text {II }}$ Docente de la Universidad Nacional de Loja, Loja Ecuador

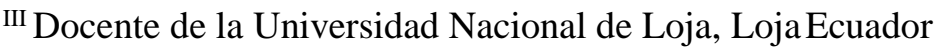

IV Docente e la Universidad Técnica de Manabí, Portoviejo, Ecuador.
} 


\title{
Resumen
}

El presente estudio tuvo como propósito determinar la incidencia de la educación a distancia en el desempeño académico de sus estudiantes. La investigación se ubicó en un estudio descriptivo y correlacional de campo. La población fue de 130 estudiantes durante el segundo semestre del año 2017. La técnica utilizada para la recolección de los datos fue la encuesta a través de un instrumento tipo cuestionario con tres alternativas de respuestas: siempre, algunas veces y nunca. La validez del instrumento fue de contenido por criterios de expertos en el área y la confiabilidad se determinó a través del Coeficiente de Alfa Cronbach, cuyo resultado fue de 0.83, considerado altamente significativo. La técnica de análisis fue la estadística descriptiva e incluye una relación chi cuadrado. Entre los resultados se evidenció que existe una relación altamente significativa de dependencia entre el desempeño académico de los estudiantes y la educación a distancia.

Palabras claves: educación a distancia; desempeño académico; autonomía; independencia.

\begin{abstract}
The purpose of this study was to determine the incidence of distance education in the academic performance of its students. The investigation was located in a descriptive and correlational field study. The population was 130 students during the second semester of 2017. The technique used to collect the data was the survey through a questionnaire-type instrument with three alternative answers: always, sometimes and never. The validity of the instrument was of content by expert criteria in the area and the reliability was determined through the Alpha Cronbach coefficient, whose result was 0.83 , considered highly significant. The analysis technique was descriptive statistics and includes a chi-square relationship. Among the results it was evidenced that there is a highly significant relationship of dependence between the academic performance of students and distance education.
\end{abstract}

Keywords: distance education; academic performance; autonomy; independence. 


\section{Resumo}

O objetivo deste estudo foi determinar a incidência da educação a distância no desempenho acadêmico de seus alunos. A investigação foi localizada em um estudo de campo descritivo e correlacional. A população foi de 130 alunos durante o segundo semestre de 2017. A técnica utilizada para coleta dos dados foi a pesquisa por meio de um instrumento do tipo questionário com três respostas alternativas: sempre, às vezes e nunca. A validade do instrumento foi de conteúdo por critério perito na área e a confiabilidade foi determinada pelo coeficiente de Alpha Cronbach, cujo resultado foi de 0,83 , considerado altamente significativo. A técnica de análise foi estatística descritiva e inclui uma relação qui-quadrado. Entre os resultados, constatou-se que existe uma relação altamente significativa de dependência entre o desempenho acadêmico dos alunos e a educação a distância.

Palavras chave: educación a distância; desempeño académico; autonomia; independência. 